\title{
Immune Gene Expression against Similar Damselfish Virus (SRDV) Induced by Immunization with Inactivated Vaccine in Juvenile Koi Carp
}

\author{
P. Sivasankar* , K. Riji John, M. Rosalind George, M. Mohamed Mansoor, \\ P. Magesh Kumar and M. Selvamagheswaran
}

Department of Fish Pathology and Health Management, School of Aquaculture, Fisheries College and Research Institute, Tamil Nadu Fisheries University, Thoothukudi - 628 008, Tamil Nadu, India

*Corresponding author

\begin{tabular}{|c|c|}
\hline & A B S T R A $\mathbf{C}$ \\
\hline & \multirow{6}{*}{$\begin{array}{l}\text { Vaccination is one of the best preventive measures against viral diseases in aquaculture. In } \\
\text { this study, experimental inactivated similar damselfish virus (SRDV) vaccine was prepared } \\
\text { and immunogenicity and protection against virus infection of the vaccine was investigated } \\
\text { in koi carp (Cyprinus carpio). Formalin-inactivated virus at } 4^{\circ} \mathrm{C} \text { for } 2 \text { days was exhibited } \\
\text { no typical clinical symptoms of SRDV infection and no mortality following challenge at } \\
\text { 28-day post-vaccination. The immune response was induced by intraperitoneal injection of } \\
\text { koi with formalin-inactivated vaccine added Quil-A }{ }^{\circledR} \text { adjuvant. The expression levels of } \\
\text { genes including IRF-7 and IL-10 in spleen of koi immunized with vaccine added Quil-A } \\
\text { adjuvant was highly up-regulated ( } 52.2 \text { fold) at } 24 \text { h post infection of the virus but in } \\
\text { kidney was showed down-regulation }(0.4 \text { fold). Interestingly, the highest level of up- } \\
\text { regulation ( } 16 \text { fold) was recorded at } 96 \text { host infection of SRDV. Like IRF-7, highest up- } \\
\text { regulation of IL-10 gene was observed in spleen of koi immunized with vaccine added } \\
\text { Quil-A }{ }^{\circledR} \text { adjuvant at } 24 \text { post infection of the virus while kidney was showed down- } \\
\text { regulation. The study provides strong evidence for the existence of expression profiles of } \\
\text { immune related genes (IRF-7 and IL-10) during the ranavirus infection. It also suggests } \\
\text { that Quil- } \mathrm{A}^{\circledR} \text { adjuvant enhances the immune response of the vaccine candidates. }\end{array}$} \\
\hline & \\
\hline $\begin{array}{l}\text { SRDV, Formalin- } \\
\text { inactivated vaccine, } \\
\text { Immune genes, } \\
\text { Expression profiles. }\end{array}$ & \\
\hline Article Info & \\
\hline $\begin{array}{l}\text { Accepted: } \\
\text { 19 July } 2017 \\
\text { Available Online: } \\
\text { 10 September } 2017\end{array}$ & \\
\hline & \\
\hline
\end{tabular}

\section{Introduction}

Viral diseases are one of the major challenges that are threatening a sustainable growth of fish farming and wild populations globally. Fish viral diseases account for large-scale mortality in farmed fish and are very difficult to treat directly. In the last decade, ranaviruses have been identified as responsible agents for causing disease outbreaks mainly in hatchery reared larvae and juveniles of a wide variety of fishes throughout the world (Whittington et al.,
2010). Ranaviruses are associated with numerous disease outbreaks in natural and cultured populations of fish, amphibians and reptiles (Chinchar, 2002; Chinchar et al., 2009). Several ranavirus isolates have been recovered from different host species in Australia, the Americas, Europe and Asia (Williams et al., 2005). Ranaviruses belong to one of the five genera of the family Iridoviridae (Jancovich et al., 2011). They are large icosahedral, double-stranded DNA 
(dsDNA) viruses usually 120-200 nm in diameter in size and with a genome size of 105 and $140 \mathrm{kbp}$ that can infect a broad range of lower vertebrates (Williams et al., 2005; Holopainen, 2012). The core of the virion consists of a nucleoprotein filament surrounded by a lipid membrane containing transmembrane proteins and a capsid composed of identical capsomers (Jancovich et al., 2011). We have isolated and characterised a ranavirus from similar damselfish, which was found to be pathogenic to seabass and similar damselfish (John and George, 2011; Sivasankar, 2014).

Vaccination of farmed fish plays an important role in commercial fish farming in order to mitigate diseases caused by many pathogens. There are several diseases which could be controlled by vaccination (Schnick et al., 1997). Inactivated vaccines generally refer to preparations of killed pathogens when referring to viral vaccines. The first generation of inactivated vaccine was developed by Louis Pasteur during 1880 (Munang'abdu et al., 2014). The inactivation methods consist into two broad categories, namely physical and chemical. Physical inactivation methods for microorganisms can be done by ultraviolet (UV) light, heat and sonication. There are different chemicals are used for preparing inactivated vaccines such as $\beta$-propiolacone (BPL) and binary ethylenimine (BEL), formalin and chloroform (Ou-yang et al., 2012; Munang'abdu et al., 2014; Ito and Maeno, 2015). Formalin is the most commonly used inactivators and demonstrated to be fairly effective in inactivating virus infectivity (Jiang et al., 2008). $\beta$-propiolactone (BPL) is another widely used chemicals to inactivate viruses for human as well as veterinary vaccine development (Lawrence, 2000).

Killed vaccines have been developed for some pathogenic fish viruses such as infectious pancreatic necrosis virus (IPNV), infectious hematopoietic necrosis virus (IHNV), viral hemorrhagic septicemia virus (VHSV) and spring viremia of carp virus (SVCV) (Hegde and Sin, 2006). Red sea bream immunized with inactivated iridoviral antigens was found to be significantly showing better protection than non-vaccinated fish after experimental infection (Nakajima et al., 1997). Fish immunized with formalininactivated vaccines have showed good protective effects against lymphocystis disease virus (LCDV) (Nakajima et al., 1997, Nakajima et al., 1999; Yoshimizu and Iwamoto, 2001). Successful use of killed VHSV in rainbow trout has also been recorded. Formalin-inactivated IHNV was found to protect rainbow trout against lethal IHNV when immunized at high virus concentration (Hegde and Sin, 2006). Immunogenicity and protective effects of inactivated Singapore grouper iridovirus (SGIV) vaccines have been investigated in orange-spotted grouper, Epinephelus coioides (Ou-yang et al., 2012). Efficacy of a formalin-killed vaccine against infectious spleen and kidney necrosis virus (ISKNV) and the major immunogenic proteins of ISKNV were found out by Dong et al., (2013).

Interferons (IFNs) are secreted mediators that play a fundamental role in the innate immune response against viruses in vertebrates (Adamek et al., 2012). Interferon regulatory factors (IRFs) are a family of transcription mediators involved in a transcriptional regulation of type 1 IFNs and IFNs stimulating genes (ISGs). IRF 7 is known as the master regulator of type 1 immune response in vertebrates and it plays a vital role in the innate antiviral immunity ( $\mathrm{Hu}$ et al., 2011). IL-10, initially known as cytokine synthesis inhibitory factor, is a multifunctional cytokine and demonstrates immunosuppressive function. The main 
function of IL-10 seems to be regulation of immunity and the inflammatory response, thereby minimizing damage to the host induced by the response to a pathogen or by the self-immune system. The expression of the IL-10 gene in head kidney, spleen, intestine and gill tissues obtained from normal (healthy) carp (Savan et al., 2003). However, a more pronounced expression of carp IL-10 was observed in head kidney and intestine tissues. In the present work, we report expression of the immune genes, IFN and IL10 in juvenile koi carp immunized with inactivated vaccine of similar damselfish virus (SRDV).

\section{Materials and Methods}

\section{Cell line}

Epithelioma papulosum cyprini (EPC) cell line was used for virus propagation and vaccine development. The cells were grown in cell culture plastic flasks $\left(25 \mathrm{~cm}^{2}\right)$ (Thermo, Korea). The cell lines were maintained in Leibovitz-15 (L-15) (Gibco, USA) medium supplemented with $10 \%$ foetal bovine serum (Gibco, USA) and 1x antibioticantimycotic solution (Gibco, USA) at $27{ }^{\circ} \mathrm{C}$.

\section{Virus}

Similar damselfish virus (SRDV) isolated from similar damselfish (Pomacentrus similis) and characterized in our laboratory was used for the present study (John and George, 2011; Sivasankar, 2014). Stock preparation of SRDV was prepared in EPC cell line. On completion of CPE, the infected culture supernatant was harvested and clarified by centrifugation at $3000 \mathrm{x} \mathrm{g}$ for 10 min. Aliquots of the cell culture supernatant containing SRDV were placed in cryotubes and stored at $-80{ }^{\circ} \mathrm{C}$ until use. One aliquot was thawed and used for estimating $\mathrm{TCID}_{50} / \mathrm{ml}$ of the virus by inoculating 10 -fold serial dilutions in 96-well microplates, seeded with newly sub-cultured EPC cell suspension. The plate was incubated at $27^{\circ} \mathrm{C}$ and development of CPE was noticed for 10 days for calculating the viral titre.

\section{Fish and rearing condition}

Healthy koi (Cyprinus carpio) were obtained (average weight $9.5 \mathrm{~g}$ ) from the local ornamental fish farm and maintained in the laboratory until non-specific mortalities had stopped and acclimatization achieved to the tank conditions. Fish were held in 1001 glass aquarium tanks maintained with $60 \quad 1$ freshwater at a temperature of $31 \pm 1{ }^{\circ} \mathrm{C}$ with a carbon re-circulating water system. Fish were fed with commercial pelleted diet twice daily. The bottom of the tanks was cleaned daily by siphoning out waste material along with a partial exchange $(10 \%)$ of water.

\section{Vaccine preparation}

To prepare vaccine, supernatants of SRDV infected EPC cell cultures were centrifuged at $1500 \mathrm{x} \mathrm{g}$ for $10 \mathrm{~min}$ at $4{ }^{\circ} \mathrm{C}$. Formalin was added to the culture supernatants (having a virus titre of $10^{7} \mathrm{TCID}_{50} \mathrm{ml}^{-1}$ ) to a final concentration of $0.1 \%(\mathrm{~V} / \mathrm{V})$ and incubated at $4{ }^{\circ} \mathrm{C}$ for 2 days. The presence of infectious virus in inactivated samples and sequential aliquots was measured by cell culture assay by passaging of treated virus samples on EPC cell monolayers for periods of up to 10 days.

\section{Vaccination and challenge}

Koi juveniles were randomly divided into 6 groups of 17 fish each in duplicate namely: control (4 tanks), vaccine alone (4 tanks) and vaccine + adjuvant (saponin Qil-A ${ }^{\circledR}$ ) (InvivoGen), (4 tanks). The concentration of adjuvant (saponine Qil-A ${ }^{\circledR}$ ) was adjusted to 5 $\mu \mathrm{g} /$ fish with sterilized double distilled water. Fish were starved for $24 \mathrm{~h}$ prior to vaccination 
and anesthetized by immersion in benzocaine (Himedia) solution at the concentration of 40 ppm. Vaccine preparations were then injected intra-peritoneally at $50 \mu \mathrm{l} / \mathrm{fish}$. Control fish received the same volume of PBS. After vaccination, each group was kept in separate aquaria glass tank and was monitored continuously.

\section{Challenge experiment}

On the 28th day post-vaccination, fish from each group were challenged by intraperitoneal injection with SRDV. Two groups of fish from each group were challenged with $50 \mu \mathrm{l}$ of the SRDV stock $\left(10^{5.17}\right.$ TCID $\left._{50} / 50 \mu \mathrm{l}\right)$. Control fish received the same volume of PBS and fish were monitored for 50 days.

\section{Transcription of immune genes post} vaccination

The transcriptional levels of immune genes IRF-7 and IL-10 were evaluated in the fish from different groups by quantitative realtime RT-PCR assays. Total RNA was isolated from the spleen and kidney tissues taken from three fish in each treatment group at $24 \mathrm{~h}, 48 \mathrm{~h}$ and $96 \mathrm{~h}$ after vaccination by using TRIzol reagent (Life Technologies) as per the manufacturer's instructions. The RNA was dissolved in $100 \mu \mathrm{l}$ of DEPC treated RNasefree water.

\section{cDNA synthesis}

The RNA concentration was adjusted to $1 \mu \mathrm{g}$ for reverse transcription to cDNA synthesis. The concentration of RNA was measured by means of a UV spectrophotometer (Hitachi High-Technologies Corporation, Tokyo Japan) at $\mathrm{OD}_{260} \mathrm{~nm}$. cDNA was synthesized from all RNA samples extracted from selected tissues using the specific reverse primers for IRF-7, IL-10 and $\beta$ actin with cDNA Synthesis Kit (Thermo, USA) according to the manufacturer's instructions The reaction mixture contained extracted RNA $(10 \mu \mathrm{l})$ with $10 \mu \mathrm{l}$ of cDNA synthesis mixture containing $2 \mu \mathrm{l}$ of specific reverse gene specific primer, $2 \mu \mathrm{l}$ of 10x RT buffer, $0.8 \mu 1$ of $25 \mathrm{x}$ dNTP, $1 \mu 1$ of multi scribe, $1 \mu 1$ of RNase inhibitor and $3.2 \mu \mathrm{l}$ nucleus-free water. The reaction mixture was incubated at $25^{\circ} \mathrm{C}$ for $10 \mathrm{~min}, 37^{\circ} \mathrm{C}$ for $160 \mathrm{~min}$ and $85^{\circ} \mathrm{C}$ for $5 \mathrm{~min}$. The cDNA thus synthesized was used for gene expression studies using quantitative real-time RT-PCR.

\section{Quantitative real-time reverse transcriptase-PCR (qRT-PCR)}

An aliquot $(2 \mu \mathrm{l})$ of the cDNA was analyzed by real-time PCR in the reaction mixture of $25 \mu \mathrm{l}$ containing $2 \mu \mathrm{l}(50 \mathrm{pmol})$ each of forward and reverse primer, $12.5 \mu \mathrm{l}$ of $2 \mathrm{x}$ power SYBR green (Thermo, USA) master mix and $6.5 \mu l$ of deionised water. The amplification was carried out in Step-One Plus Real-Time PCR Detection system (ABI, Invitrogen, Life sciences, USA). The expression level of the immune genes in the samples was analyzed in triplicate using the comparative threshold cycle method $\left(2-^{\Delta \Delta \mathrm{CT}}\right)$ with $\beta$-actin gene as an internal control. The primers used for qRT-PCR immune genes and cycling conditions have been listed in the table 1 .

\section{Results and Discussion}

\section{Protection of inactivated SRDV vaccination}

On the 28th day post-vaccination, fish from each group were challenged with SRDV and fishes were maintained for 50 days after viral challenge along with control. In challenge trials, the fish showed no typical clinical symptoms of SRDV infection and no mortality was recorded from all groups during the study period (Fig. 1). 


\section{Immune gene expression}

Spleen, kidney and thymus are considered the major lymphoid organs in fish (Rombout et $a l ., 2005)$ and represent suitable sources for immune cells which respond to viral infection (Rakus et al., 2012, Ouyang et al., 2013). Expression of IRF-7 gene and IL-10 were tested in koi with SRDV infection alone, SRDV infected fish vaccinated with formalininactivated SRDV vaccine and SRDV infected fish vaccinated with formalininactivated SRDV vaccine + Qil-A ${ }^{\circledR}$ adjuvant.

\section{Expression of IRF-7 in spleen after virus} infection

As shown in figure 2, IRF-7 expression in spleen of koi immunized with vaccine plus Quil-A ${ }^{\circledR}$ adjuvant was highly up-regulated (52.2 fold) at $24 \mathrm{~h}$ post infection with SRDV. When the fish are immunized with inactivated SRDV vaccine alone and inactivated SRDV vaccine with Quil-A ${ }^{\circledR}$ adjuvant were challenged by virus administration, it showed 17 and 5 fold induction respectively after $48 \mathrm{~h}$. When the fish are infected with SRDV alone, it showed 11 fold inductions. No expression was noticed after $96 \mathrm{~h}$.

\section{Expression of IRF-7 gene in kidney after virus infection}

In contrast, the expression of IRF-7 in kidney koi immunized with vaccine added Quil- ${ }^{\circledR}$ adjuvant did not show up-regulation at $24 \mathrm{~h}$ post infection (Fig. 3). The highest level of up-regulation (16 fold) was recorded at $96 \mathrm{~h}$ post infection of SRDV in fish vaccinated with adjuvant. The expression of IRF-7 in kidney was up-regulated in fish infected with virus alone at all three-time points $(2.2,9.3$ and 2.7 fold) respectively when compared to control group. Overall the results show that IRF-7 is up-regulated in both spleen and kidney of koi in responses to SRDV infection.
Expression of IL-10 gene in spleen after virus infection

Changes in gene expression of IL-10 in spleen and kidney tissues obtained from koi at $24 \mathrm{~h}$, $48 \mathrm{~h}$ and $96 \mathrm{~h}$ after SRDV infection was analysed. The levels of IL-10 expression in spleen of vaccine + adjuvant and vaccine alone groups showed high fold induction of 331 and 224 fold respectively when compared to those in non-vaccinated fish at $24 \mathrm{~h}$ postvaccination (Fig. 4). The level of IL-10 gene expression in spleen was found decreased later and stood slightly up-regulated (1.8 fold) in virus infected group while the vaccinated group at $96 \mathrm{~h}$ post infection with SRDV was up-regulated at 8 fold.

\section{Expression of IL-10 gene in kidney after} virus infection

Unlike to the expression of IL-10 in spleen, its expression in kidney of koi immunized with vaccine alone and unvaccinated group showed up-regulation at 28.9 and 29.6 fold at $24 \mathrm{~h}$ post viral challenge. The expression of IL-10 continued up-regulated at $48 \mathrm{~h}$ in both the above groups. In fish vaccinated with adjuvant slight up-regulation was noticed (4.1 fold) at $96 \mathrm{~h}$ (Fig. 5). Overall the results show that IL-10 is up-regulated in both spleen and kidney of koi in responses to SRDV infection.

Iridovirus induced mortality remains as an important constraint in the sustainable aquaculture of cultivable and ornamental fish.

The genus Rana virus of the family of Iridoviridae includes several major pathogens of economically and ecologically important fishes, which are associated with numerous disease outbreaks in the natural and cultured population of fish. Ranavirus disease outbreaks also have high mortality among freshwater and marine ornamental fish farms. The chemicals and/or antimicrobial 
treatments are being discouraged because of leading to the development of resistance in the microorganisms and posing negative impacts to the aquatic environments (Ou-yang et al., 2012). Vaccination has become a powerful tool for health management in aquaculture in term of prevention of diseases and several vaccines against viral and bacterial diseases have been successfully developed (Fu et al., 2014).

Fig.1 Experimental design of juvenile koi fish following similar damselfish virus

(SRDV) infection

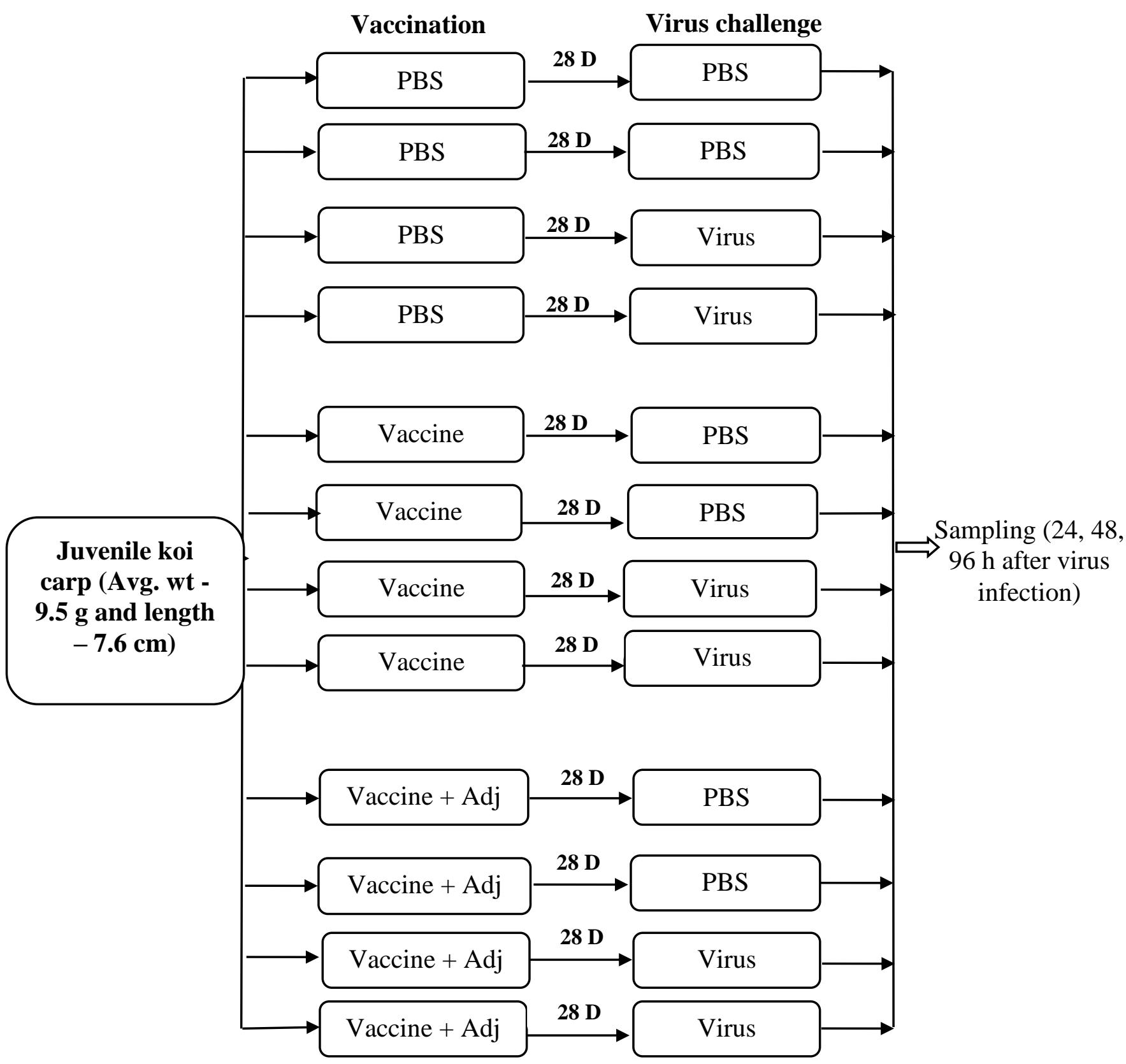

Adj- Adjuvant 
Fig.2 Relative folds induction $\left(2^{-\Delta \Delta C T}\right)$ of IRF-7gene in spleen of koi fish challenged with SRDV at $24 \mathrm{~h}, 48 \mathrm{~h}$ and $96 \mathrm{~h}$

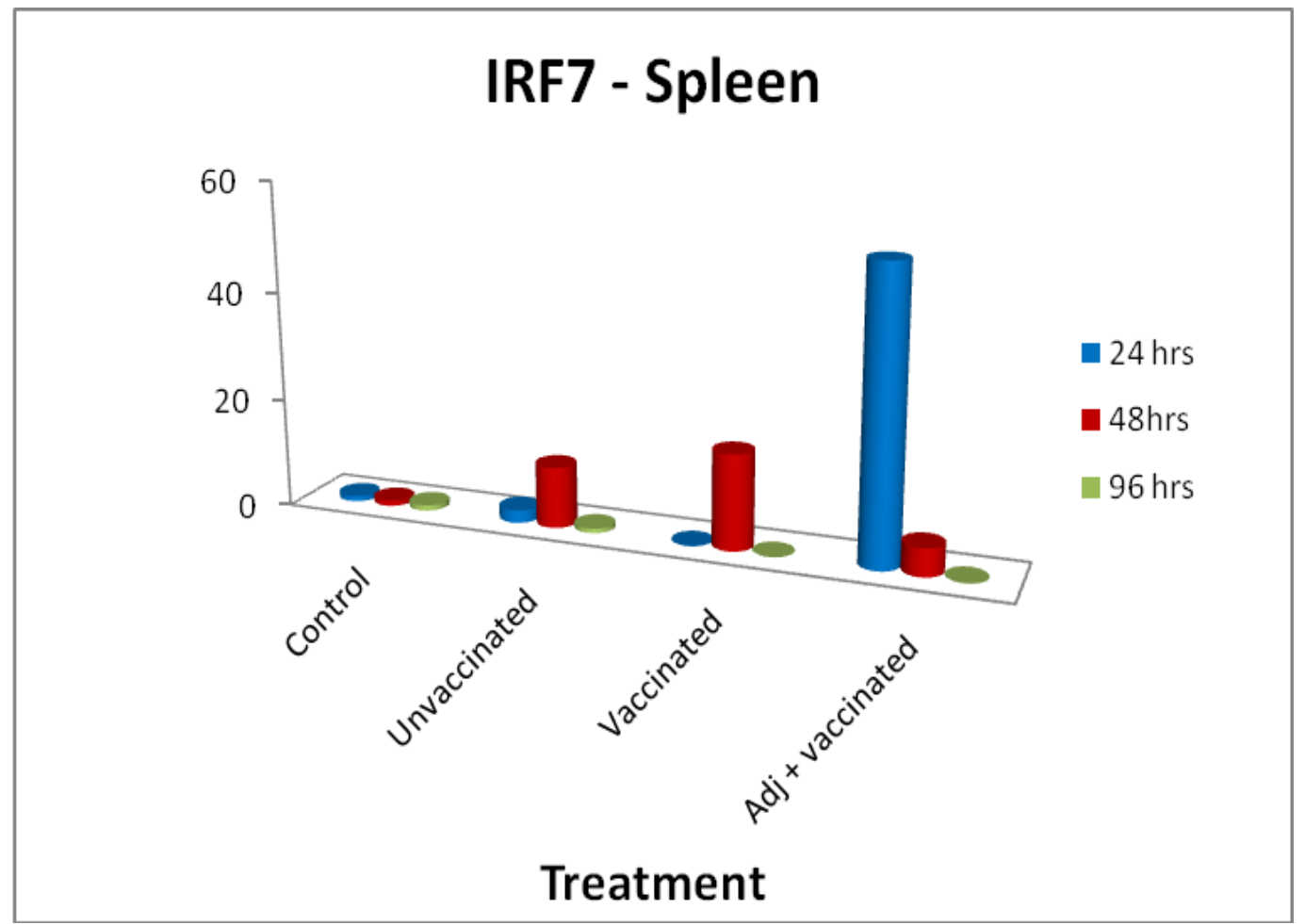

Fig.3 Relative folds induction $\left(2^{-\Delta \Delta C T}\right)$ of IRF-7gene in Kidney of koi fish challenged with SRDV at $24 \mathrm{~h}, 48 \mathrm{~h}$ and $96 \mathrm{~h}$

\section{IRF7 - Kidney}

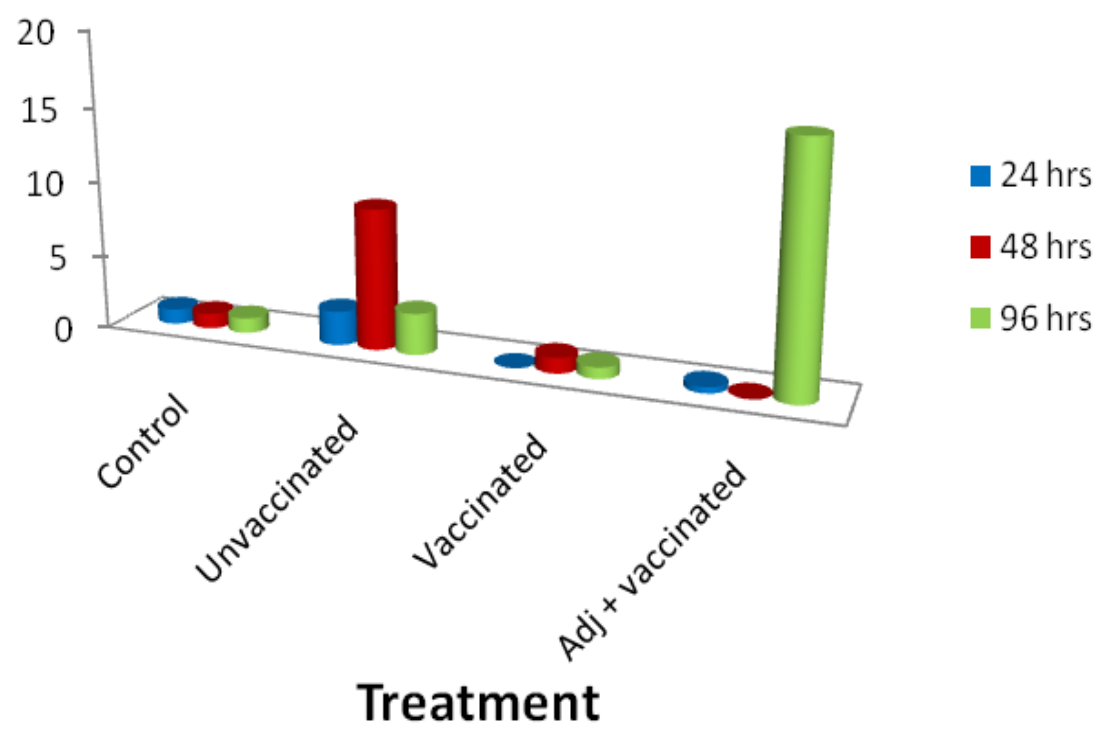


Fig.4 Relative folds induction $\left(2^{-\Delta \Delta C T}\right)$ of IL-10 gene in spleen of koi fish challenged with SRDV at $24 \mathrm{~h}, 48 \mathrm{~h}$ and $96 \mathrm{~h}$

\section{IL-10 - Spleen}

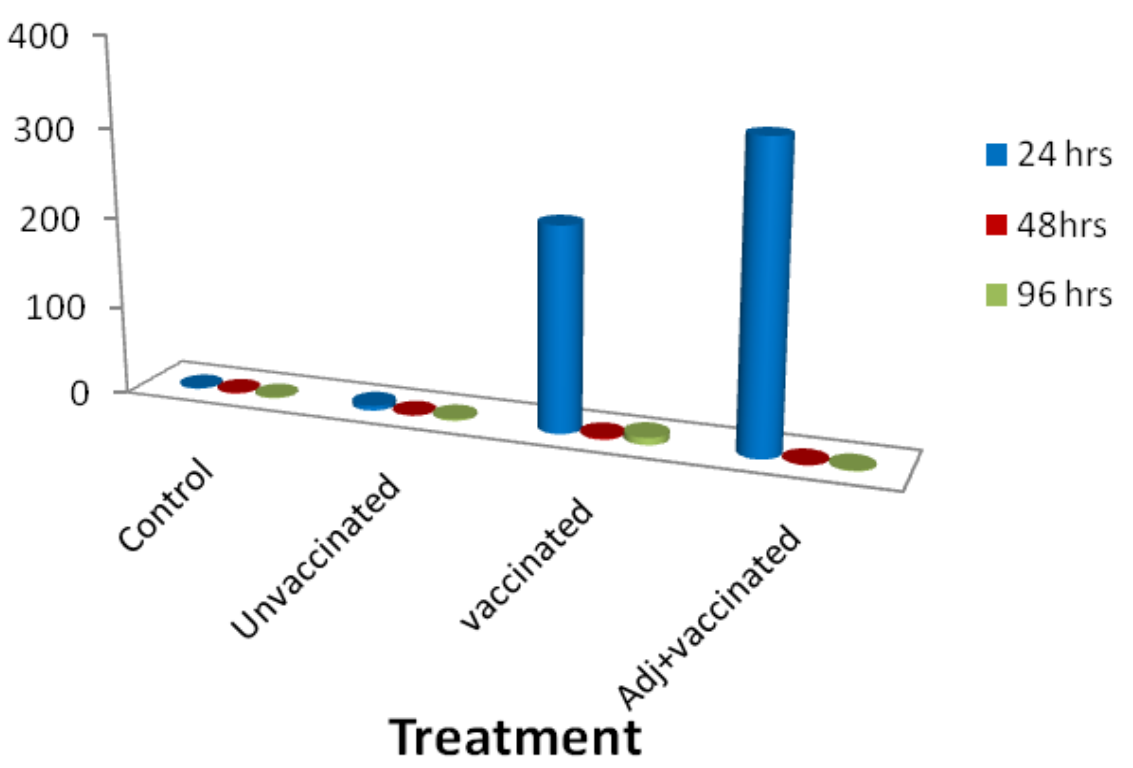

Fig.5 Relative folds induction $\left(2^{-\Delta \Delta C \mathrm{~T}}\right)$ of IL-10 gene in Kidney spleen of koi fish challenged with SRDV at $24 \mathrm{~h}, 48 \mathrm{~h}$ and $96 \mathrm{~h}$

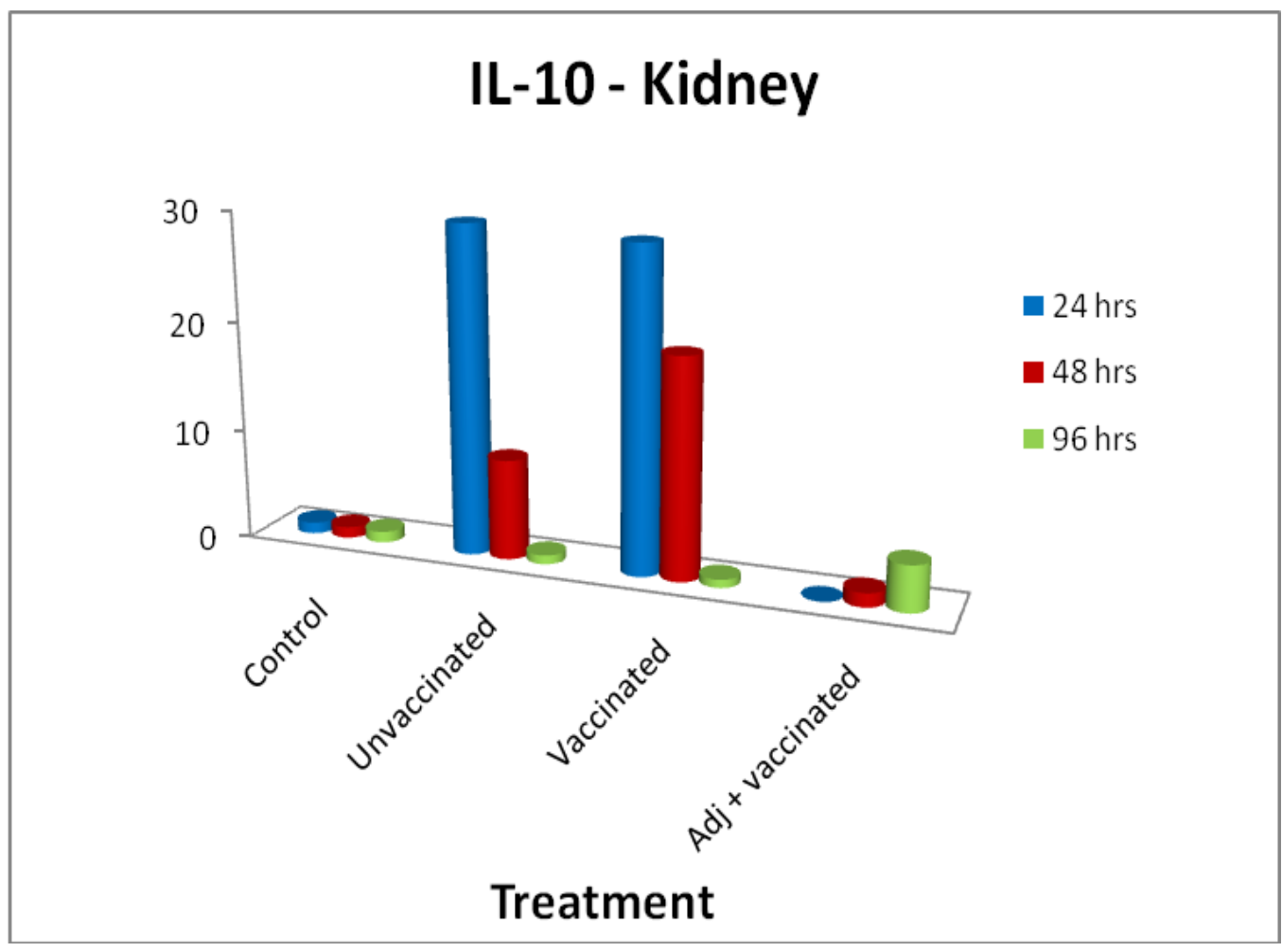


Table.1 Primers used for the qRT PCR analysis of IRF7 and IL10 gene expression following SRDV challenge

\begin{tabular}{|c|c|c|c|c|}
\hline Gene & Primers sequence $5^{\prime}-3^{\prime}$ & Accession number & Size (bp) & Cycling condition \\
\hline $\begin{array}{l}\text { IRF-7 Fw2 } \\
\text { IRF-7 Rv2 }\end{array}$ & $\begin{array}{l}\text { TCCACTGAGGGTCTGATTGA } \\
\text { CGCTGGTGCTGACGAAGA }\end{array}$ & JQ698666 & 148 & $\begin{array}{l}95^{\circ} \mathrm{C} 10 \mathrm{~min} \\
95^{\circ} \mathrm{C} 15 \mathrm{sec} \\
55^{\circ} \mathrm{C} 1 \mathrm{~min} \\
72^{\circ} \mathrm{C} 1 \mathrm{~min}\end{array}$ \\
\hline $\begin{array}{l}\text { IL-10 Fw3 } \\
\text { IL-10 Fv3 }\end{array}$ & $\begin{array}{l}\text { TGATGATTTGGAACCATTATTGAA } \\
\text { CACCTTTTTCCTTCATCTTTTCAT }\end{array}$ & KX622694 & 284 & $\begin{array}{l}95^{\circ} \mathrm{C} 10 \mathrm{~min} \\
95^{\circ} \mathrm{C} 15 \mathrm{sec} \\
56^{\circ} \mathrm{C} 1 \mathrm{~min} \\
72^{\circ} \mathrm{C} 1 \mathrm{~min}\end{array}$ \\
\hline $\begin{array}{l}\beta \text {-actin Fw } \\
\beta \text {-actin Rv }\end{array}$ & $\begin{array}{l}\text { TCACCACCACAGCCGAGAG } \\
\text { CAGGGAGGAGGAGGAAGCAG }\end{array}$ & M24113 & 110 & $\begin{array}{l}95{ }^{\circ} \mathrm{C} 10 \mathrm{~min} \\
95{ }^{\circ} \mathrm{C} 15 \mathrm{sec} \\
54{ }^{\circ} \mathrm{C} 1 \mathrm{~min} \\
72^{\circ} \mathrm{C} 1 \mathrm{~min}\end{array}$ \\
\hline
\end{tabular}

Formalin inactivation of the virus has been effectively used to develop safe and efficacious human and veterinary vaccines (Ou-yang et al., 2012). RT-PCR assays are usually carried out to measure the expression of immune genes in vaccination experiments to assess the efficacy of vaccine preparations and delivery of vaccine candidates. IRF-7 is a master regulator of type-I interferondependent immune responses and is essential for the induction of IFN-a/b genes (Fu et al., 2014). IL-10 is the most important immunoregulatory cytokine produced by various types of cells (Nam et al., 2014).

The present study describes the expression of two important immune genes that has specific roles in antiviral activity upon SRDV infection in juvenile koi carp following immunization with inactivated vaccine with and without an adjuvant. In our study, expression of IRF-7 up-regulated in the spleen of koi immunized with vaccine added Quil-A $^{\circledR}$ adjuvant (52.2 fold) at $24 \mathrm{~h}$ post infection with SRDV then decreased at 48 and $96 \mathrm{~h}$. Similar increase first at $48 \mathrm{~h}$ followed by decreasing trend across a 21 day period was also reported in Chinese perch post vaccination with QCDC + pcMCP (Fu et al.,
2014). Similar observation was noticed in the group of fish immunized with inactivated vaccine where IRF expression increased to 17 fold at $48 \mathrm{~h}$ and declined by $96 \mathrm{~h}$. In kidney of koi, IRF-7 was up-regulated 16 fold at $96 \mathrm{~h}$ post infection of SRDV in the group administered with vaccine plus adjuvant. Expression was subdued in vaccinated fish without adjuvant during all the time points. Expression of IRF7 was however noticed in challenged fish of unvaccinated group. In the kidney of golden mandarin fish, the immune genes such as IRF2, IRF7, Mx and IRF1 showed significant changes in mRNA expression levels at $1 \mathrm{dpi}$ with infectious spleen and kidney necrosis virus (ISKNV) like agent (Shin et al., 2013). In skin and head kidney of two genetic lines of common carp (Cyprinus carpio), CyHV-3 induced a strong mRNA expression by up-regulating both IRFs 3 and 7 at 72 and $120 \mathrm{hpi}$, and at 24, 72 and 120 hpi, respectively (Adamek et al., 2014).

IL10 expression was very high in the spleen of koi in the current study after $24 \mathrm{~h}$ of challenge in both groups of vaccinated fishes. Up-regulation of IL10 in fish in response to bacterial and viral infection has been reported (Nam et al., 2014). Formalin and BPL 
inactivated SGIV vaccine administered grouper fish induced the expression of IL-8 in the spleen with a peak of 2.0-fold at day 7 and 2.2-fold at day 1 respectively (Ou-yang et al., 2012). In our study, the levels of IL-10 gene expression was up-regulated at 224 fold in vaccinated group while the gene expression was 331 fold in vaccine plus adjuvant group after the virus challenge. Unvaccinated controls did not show any induction of IL10. IL-8 demonstrated a peak in mRNA expression at $10 \mathrm{dpi}$ in spleen of golden mandarin fish following ISKNV-like agent challenge (Shin et al., 2013). Significant upregulation of carp IL-10 in the spleen was noted during the acute phase of $\mathrm{CyHV}-3$ infection, but not during the persistent and reactivation phases (Sunarto and McColl, 2015). They also observed that the IL-10 host gene and the CyHV-3v IL-10 gene (khvIL10) were expressed at significantly higher levels during all phases of $\mathrm{CyHV}-3$ infection compared with mock-infected common carp. In the kidney of golden mandarin fish, IL-8 demonstrated a peak in mRNA expression at $4 \mathrm{dpi}$ and then returned to basal level or decreased slightly with ISKNV-like agent challenge (Shin et al., 2013). Significant mRNA expression of IL-10 in the kidney of olive flounder was observed at $1 \mathrm{~h}$ post infection and the highest level of upregulation was noted at $6 \mathrm{~h}$ (3 fold) following VHSV challenge (Nam et al., 2014). In the present study, IL-10 gene was highly upregulated at $24 \mathrm{~h}$ post viral challenge in the kidney in both unvaccinated and vaccinated (without adjuvant) fish (29.6 and 28.9 fold). The expression was reduced at $48 \mathrm{~h}$ in both the cases. IL-10 gene upregulation (4.1 fold) was observed at $96 \mathrm{~h}$ in the kidney of koi immunized with vaccine added Quil-A ${ }^{\circledR}$ adjuvant. The expression of IL-10 mRNA in kidney tissue of olive flounder fish was highly up-regulated (2.7 fold) at $24 \mathrm{~h}$ post infection with Edwardsiella tarda (Nam et al., 2014). Overall the results show that IL-10 is up- regulated in both spleen and kidney of koi in responses to SRDV infection at $24 \mathrm{~h}$.

Protection against various pathogens is a major challenge faced by aquaculturists and researchers because of the development of serious diseases associated with large-scale aquaculture. Our results demonstrate that inactivated SRDV prepared from supernatants of SRDV infected EPC cells by formalin at $4^{\circ} \mathrm{C}$ for 2 days could trigger immune gene expression following SRDV challenge, which is an indication of the immunity development in fish. The effective vaccination is capable of inducing immune-related genes involving the immune system of fish. The study provides strong evidence for the upward modulation of expression profiles of immune-related genes (IRF-7 and IL-10) during the ranavirus infection. The study also suggests that Quil$\mathrm{A}^{\circledR}$ adjuvant enhances the immune response of the vaccine candidates.

\section{Acknowledgement}

Authors thank NFDB-NBFGR for the funding support. The study formed the part of the Ph.D thesis of the first author.

\section{References}

Adamek, M., Rakus, K. Ł., Brogden, G., Matras, M., Chyb, J., Hirono, I., Kondo, H., Aoki, T., Irnazarow, I., and Steinhagen, D. 2014. Interaction between type I interferon and Cyprinid herpesvirus 3 in two genetic lines of common carp Cyprinus carpio. Diseases of Aquatic Organisms. 111(2): 107-118.

Adamek, M., Rakus, K. Ł., Chyb, J., Brogden, G., Huebner, A., Irnazarow, I., and Steinhagen, D. 2012. Interferon type I responses to virus infections in carp cells: In vitro studies on Cyprinid herpesvirus 3 and Rhabdovirus carpio infections. Fish \& Shellfish Immunology. 33(3): 482-493.

Chinchar, V. G., 2002. Ranaviruses (family Iridoviridae): emerging cold-blooded killers. Archive of Virology. 147(3): 447- 
470.

Chinchar, V. G., Hyatt, A., Miyazaki, T., and Williams, T. 2009. Family Iridoviridae: poor viral relations no longer. In: Lesser Known Large dsDNA Viruses, Springer Berlin Heidelberg, pp. 123-170.

Dong, Y., Weng, S., He, J., and Dong, C. 2013. Field trial tests of FKC vaccines against RSIV genotype Megalocytivirus in cagecultured mandarin fish (Siniperca chuatsi) in an inland reservoir. Fish \& Shellfish Immunology. 35(5): 1598-1603.

Fu, X., Li, N., Lin, Q., Guo, H., Zhang, D., Liu, L., and $\mathrm{Wu}, \mathrm{S}$. 2014. Protective immunity against infectious spleen and kidney necrosis virus induced by immunization with DNA plasmid containing MCP gene in Chinese perch Siniperca chuatsi. Fish \& Shellfish Immunology. 40(1): 259-266.

Hegde, A., and Sin, Y. M. 2006. Advances in fish vaccine. In: Swain, P., P. K. Sahoo and S. Ayyappan, (Ed), Fish and shell fish immunology: An introduction, Narendra publishing house, Delhi, India, pp. 191-206.

Holopainen, R., Tapiovaara H., and Honkanen J. 2012. Expression analysis of immune response genes in fish epithelial cells following ranavirus infection. Fish \& Shellfish Immunology. 32(6): 1095-1105.

Hu, G., Yin, X., Lou, H., Xia, J., Dong, X., Zhang, J., and Liu, Q. 2011. Interferon regulatory factor 3 (IRF-3) in Japanese flounder, Paralichthys olivaceus: sequencing, limited tissue distribution, inducible expression and induction of fish type I interferon promoter. Developmental and Comparative Immunology. 35(2): 164173.

Ito, T., and Maeno, Y. 2015. Effect of booster shot and investigation of vaccination efficacy period against herpesviral haematopoietic necrosis (HVHN) in goldfish Carassius auratus. Veterinary microbiology. 175(1): 139-144.

Jancovich, J. K., Chinchar, V. G., Hyatt, A., Miyazaki, T., and Zhang, Q. Y., 2011. Family Iridoviridae. In: King A. M. Q., Adams, M. J. Carstens E. B., and Lefkowitz E. (Ed.) Virus Taxonomy: Ninth Report of the International Committee on Taxonomy of Viruses. Academic Press, Elsevier, pp.
193-210.

Jiang, B., Wang, Y., Saluzzo, J. F., Bargeron, K., Frachette, M. J., and Glass, R. I. 2008. Immunogenicity of a thermally inactivated rotavirus vaccine in mice. Human Vaccines. 4(2): 143-147.

John, K. R., and George, M. R. 2011. Development and characterization of cell lines from clownfish (Amphiprion sp.) and their applications, Completion Report of the DBT Project, Tuticorin: Department of Aquaculture, Fisheries College and Research Institute.

Lawrence, S. A., 2000. Beta-Propiolactone: viral inactivation in vaccines and plasma products. PDA Journal of Pharmaceutical Science and Technology. 54(3): 209.

Munang'andu, H. M., Mutoloki, S., and Evensen, Ø. 2014. Non-replicating Vaccines, In: Gudding, R., Lillehaug, A., and Evensen, Ø. (Ed.) Fish Vaccination, John Wiley \& Sons, Ltd, UK, pp. 12-21,

Nakajima, K., Maeno, Y., Honda, A., Yokoyama, K., Tooriyama, T., and Manabe, S. 1999. Effectiveness of a vaccine against red sea bream iridoviral disease in a field trial test. Diseases of Aquatic Organisms. 36(1): 73-75.

Nakajima, K., Maeno, Y., Kurita, J., and Inui, Y. 1997. Vaccination against red sea bream iridoviral disease in red sea bream. Fish Pathology. 32(4): 205-209

Nakajima, K., Maeno, Y., Kurita, J., and Inui, Y. 1997. Vaccination against red sea bream iridoviral disease in red sea bream. Fish Pathology. 32(4): 205-209.

Nam, B. H., Moon, J. Y., Park, E. H., Kim, Y. O., Kim, D. G., Kong, H. J., Kim, W.J., Jung, H., Jee, Y.J., Lee, S.J., An, C.M. 2014. Conserved gene structure and function of interleukin-10 in teleost fish. Journal of Animal and Veterinary. Advances. 13(12): 774-782.

Ouyang, P., Rakus, K., Boutier, M., Reschner, A., Leroy, B., Ronsmans, M., Fournier, G., Scohy, S., Costes, B., Wattiez, R., and Vanderplasschen, A. 2013. The IL-10 homologue encoded by cyprinid herpesvirus 3 is essential neither for viral replication in vitro nor for virulence in vivo. Veterinary Research. 44(1): 53. 
Ou-yang, Z., Wang, P., Huang, X., Cai, J., Huang, Y., Wei, S., Ji, H., Wei, J., Zhou, Y., and Qin, Q. 2012. Immunogenicity and protective effects of inactivated Singapore grouper iridovirus (SGIV) vaccines in orange-spotted grouper, Epinephelus coioides. Developmental and Comparative Immunology. 38(2): 254-261.

Rakus, K.Ł., Irnazarow, I., Adamek, M., Palmeira, L., Kawana, Y., Hirono, I., Kondo, H., Matras, M., Steinhagen, D., Flasz, B., and Brogden, G., 2012. Gene expression analysis of common carp (Cyprinus carpio L.) lines during Cyprinid herpesvirus 3 infection yields insights into differential immune responses. Developmental and Comparative Immunology. 37(1): 65-76.

Rombout, J. H. W. M., Huttenhuis, H. B. T., Picchietti, S., Scapigliati, G. 2005. Phylogeny and ontogeny of fish leucocytes. Fish \& Shellfish Immunology. 19(5): 441-455.

Savan, R., Igawa, D., and Sakai, M. 2003. Cloning, characterization and expression analysis of interleukin- 10 from the common carp, Cyprinus carpio L. European Journal of Biochemistry. 270(23): 4647-4654.

Schnick, R. A., Alderman, D. J., Armstrong, R., Le Gouvello, R., Ishihara, S., Lacierda, E. C., Percival, S., and Roth, M. 1997. Worldwide aquaculture drug and vaccine registration progress. Bulletin of the European Association of Fish Pathologists. 17(6): 251-260

Shin, Y. J., Kwon, T. H., Seo, J. Y., and Kim, T. J. 2013. Oral immunization of fish against iridovirus infection using recombinant antigen produced from rice callus. Vaccine. 31(45): 5210-5215.

Sivasankar, P., 2014. Characterization of viral agent isolated from infected marine ornamental fish. Ph.D Thesis, Tamil Nadu Fisheries University, Nagapattinam, India.

Sunarto, A., and McColl, K. A. 2015. Expression of immune-related genes of common carp during cyprinid herpesvirus 3 infection. Diseases of Aquatic Organisms. 113(2): 127-135.

Whittington, R. J., Becker, J. A., and Dennis, M. M. 2010. Iridovirus infections in finfishCritical review with emphasis on ranaviruses. Journal of Fish Diseases. 33: 95-122.

Williams, T., V. Barbosa-Solomieu and V. G. Chinchar, 2005. A decade of advances in iridovirus research. Advance Virus Research. 65: 173-248.

Yoshimizu, M., Iwamoto, R. 2001. The development of protective vaccine against Japanese flounder lymphocystis disease using an inactivated virus. Fish Disease Center News, Annual Reports of Fish Disease Control FIDIC, 1-14.

\section{How to cite this article:}

Sivasankar, P., K. Riji John, M. Rosalind George, M. Mohamed Mansoor, P. Magesh Kumar and Selvamagheswaran, M. 2017. Immune Gene Expression against Similar Damselfish Virus (SRDV) Induced by Immunization with Inactivated Vaccine in Juvenile Koi Carp. Int.J.Curr.Microbiol.App.Sci. 6(9): 1391-1402. doi: https://doi.org/10.20546/ijcmas.2017.609.169 